Top Heterocycl Chem (2007) 11: 303-323

DOI 10.1007/7081_2007_072

(C) Springer-Verlag Berlin Heidelberg

Published online: 1 August 2007

\title{
Antiviral and Antimicrobial Evaluation of Some Heterocyclic Compounds from Turkish Plants
}

\author{
Ilkay Orhan ${ }^{1}(\bowtie) \cdot$ Berrin Özcelik $^{2} \cdot$ Bilge Şener $^{1}$ \\ ${ }^{1}$ Department of Pharmacognosy, Gazi University, 06330 Ankara, Turkey \\ iorhan@gazi.edu.tr \\ ${ }^{2}$ Department of Pharmaceutical Microbiology, Faculty of Pharmacy, Gazi University, \\ 06330 Ankara, Turkey
}

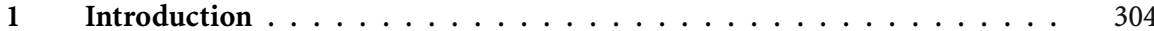

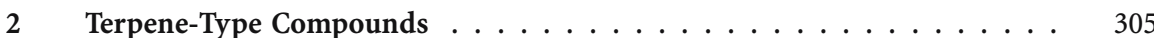

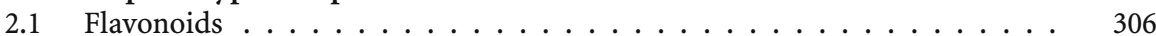

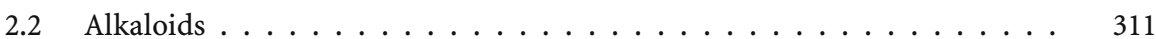

2.2 .1 Diterpene Alkaloids . . . . . . . . . . . . . . . . . . 311

2.2 .2 Isoquinoline Alkaloids . . . . . . . . . . . . . . . 315

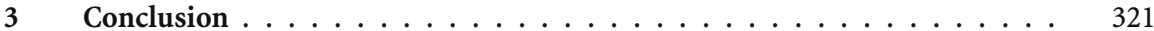

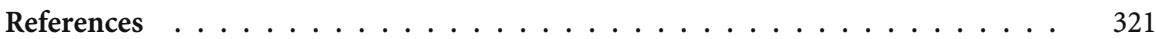

Abstract Antibiotic resistance has become a problem since the discovery of antibiotics. Not long after the introduction of penicillin, Staphylococcus aureus, which can be also transmitted to humans via milk and milk products, began developing penicillin-resistant strains. Therefore, one approach that has been used for the discovery of new antimicrobial agents from natural sources is based on the evaluation of traditional plant extracts. Natural products have played a pivotal role in antibiotic drug innovation and include aminoglycosides, cephalosporins, macrolides, cycloserine, novobiocin, and lipoproteins. However, only a few antiviral agents are available on the market. To this purpose, we have screened a great number of herbal extracts along with some pure natural substances and obtained interesting findings. This chapter covers the results of our rigorous search for new antiviral and antimicrobial alternative compounds from a number of Turkish plants.

Keywords Antimicrobial - Antiviral · Cytotoxicity · Natural compound · Plant extract

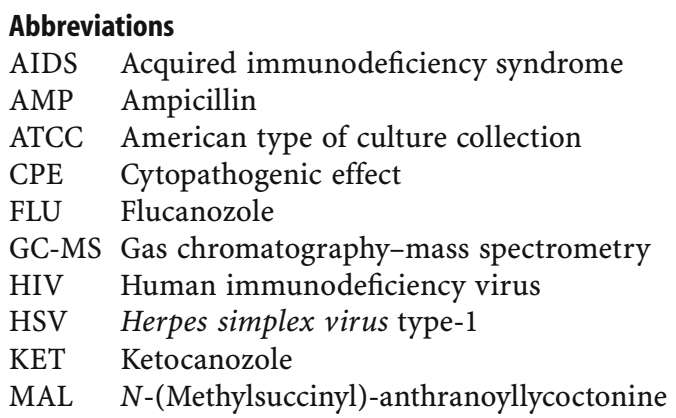




$\begin{array}{ll}\text { MDBK } & \text { Madin-Darby bovine kidney } \\ \text { MIC } & \text { Minimum inhibitory concentration } \\ \text { MNTC } & \text { Maximum non-toxic concentration } \\ \text { MRSA } & \text { Methycillin-resistant Staphylococcus aureus } \\ \text { OFX } & \text { Oflaxocin } \\ \text { PI-3 } & \text { Parainfluenza type-3 } \\ \text { SAR } & \text { Structure-activity relationship } \\ \text { TNF } & \text { Tumor necrosis factor } \\ \text { WHO } & \text { World Health Organization }\end{array}$

\section{1}

\section{Introduction}

Since their discovery during the twentieth century, antimicrobial agents (antibiotics and related medicinal drugs) have substantially reduced the threat posed by infectious diseases. On the other hand, antibiotic resistance can be defined as the ability of any microorganism to withstand the effects of an antibiotic, which is a specific type of drug resistance and evolves naturally via natural selection through random mutation [1,2]. The antibiotic action is an environmental pressure; those bacteria that have a mutation allowing them to survive will live on to reproduce. They will then pass this trait to their offspring, which will be a fully resistant generation $[3,4]$. Without doubt, antibiotic resistance is a global issue. Because of cross-continental travel of both humans and goods, antibiotic-resistant bacteria are spread from one country to another. Therefore, antibiotic resistance has been called one of the world's most pressing public health problems.

Much evidence supports the view that the total consumption of antimicrobials is the critical factor in selecting resistance. Paradoxically, underuse through lack of access, inadequate dosing, poor adherence, and substandard antimicrobials may play as an important role as overuse $[5,6]$. Since misuse of antibiotics jeopardizes the usefulness of essential drugs, decreasing inappropriate antibiotic use is the ideal way to control resistance [7]. Natural selection of penicillin-resistant strains in a bacterium known as Staphylococcus aureus began soon after penicillin was introduced in the 1940s. Recently more hospital-acquired infections are becoming resistant to the most powerful antibiotics available, such as vancomycin, which emerged in the United States in 2002, presenting physicians and patients with a serious problem [8]. A number of cases of community-associated methycillin-resistant S. aureus (MRSA) have also been reported, including cases in patients without established risk factors [9].

Modern medical science and practice have something of an armory of effective tools, ranging from antiseptics and anesthetics to vaccines and antibiotics. However, one field has been weak in finding drugs to deal with viral infections, although viral diseases have affected humans many centuries. The 
emergence of antivirals is the product of a greatly expanded knowledge of the genetic and molecular function of organisms, allowing biomedical researchers to understand the structure and function of viruses.

On the other hand, herbal medicine is the oldest form of healthcare known to mankind and has been used by all cultures throughout history. The World Health Organization (WHO) estimates that 4 billion people, $80 \%$ of the world population, presently use plants for some aspect of primary health care. WHO also notes that of 119 plant-derived pharmaceutical medicines, about $74 \%$ are used in modern medicine in ways that correlate directly with their traditional uses as plant medicines by native cultures.

In our ongoing study on the plant extracts and their pure compounds from Turkish medicinal plants, we have so far screened a number of plant extracts and pure components for their antimicrobial and antiviral activities. In this chapter, we intend to cover the recent results obtained from our antimicrobial and antiviral studies on heterocyclic compounds isolated from several Turkish medicinal plants and marine organisms.

\section{2}

\section{Terpene-Type Compounds}

Although biodiversity in terrestrial environments is extraordinary, oceans covering more than $70 \%$ of our planet represent a greater diversity of life. A small number of marine plants, animals, and microbes have already yielded over 12000 novel compounds [10]. Among them, a great number of substances of marine origin have been reported to possess antimicrobial activity such as loloatins A-D, myticins A and B, psammaplin A, etc., which have been covered in several excellent reviews [10-12].

In our previous study, ten terpene-type compounds, which we isolated from the marine sponges Ircinia spinulosa and Spongia officinalis of the Aegean Sea collection, were assayed against the American-type culture collection (ATCC) strains of Bacillus subtilis (6633), S. aureus (6536), Pseudomonas aeruginosa (9027), and Escherichia coli (8739) by the disk diffusion method [13]. The results were evaluated by comparing the inhibition zones of the compounds, namely, furospinulosin-1, furospongin-1, 2-(hexaprenylmethyl)-2-methylchromenol, heptaprenyl-p-quinol, 12-epi-deoxoscalarin, 1,4,44-trihydroxy-2-octa-prenylbenzene, demethylfurospongin4, 4-hydroxy-3-octaprenylbenzoic acid, 4-hydroxy-3-tetraprenylacetic acid, and 11- $\beta$-acetoxy-12-en-16-one. We found that furospinulosin-1, furospongin-1, 2-(hexaprenylmethyl)-2-methylchromenol, and heptaprenyl-p-quinol did not exhibit any inhibition against those bacterium strains, whereas 12-epi-deoxoscalarin (1) exerted a weak activity against B. subtilis and S. aureus, causing inhibition zones of 12 and $11 \mathrm{~mm}$ in diameter, respectively (Fig. 1). Demethylfurospongin-4 (2), 4-hydroxy-3-tetraprenylacetic acid (3), 
and 11- $\beta$-acetoxy-12-en-16-one (4) were also active against Gram-positive bacteria (Fig. 1). Among them, 4-hydroxy-3-tetraprenylacetic acid (3) was the most effective causing $20 \mathrm{~mm}$ of inhibition zone (Fig. 1). None of the compounds tested had an ability to inhibit $E$. coli. Owing to scarcity of the compounds, only one concentration $(0.5 \mathrm{mg} /$ disk $)$ could be tested. In conclusion, we suggested that this assay should be better with higher yield, if repeated.

In a similar study reported previously, 23 hydroquinone and quinone derivatives from the sponge Ircinia spinulosa were tested for their antibacterial activity, and relevant structure-activity relationships (SAR) were established [14]. As a consequence, SAR studies indicated that the optimum length of side chain in the compounds for antibacterial activity should be 5-15 carbon atoms, which is in accordance with our most effective compound, 4-hydroxy-3-tetraprenylacetic acid (3). Besides, it was reported that long-chain alcohols exert higher antimicrobial activity compared to the corresponding acids and aldehydes [15]. Similarly, a relationship between antibacterial activity and the structure of aliphatic alcohols was described, which suggested that maximum activity against $S$. aureus might be depend on the number of carbon atoms in hydrophobic chain. This should be less than 12 , but as close to 12 as possible [16]. However, according to the study of Inoue et al., this finding did not support the anti-Stapylococcus effect of the aliphatic terpene alcohols, farnesol, nerolidol, and plaunotol, which may result from configuration of functional groups and double bonds that affected activity [17]. Therefore, in that study, it was concluded that antiStapylococcus activity depends not only on aliphatic side chains, but also on the configurations of functional groups and double bonds. Possibly, the difference observed in the antibacterial effect of our compounds might be due to this reason as well.

\section{1 \\ Flavonoids}

Flavonoids are a group of polyphenolic compounds ubiquitous in many plants, in which they occur as the free forms, glycosides, as well as as methylated derivatives. In addition to their diverse biological activities, there is an increasing interest in flavonoids due to their anti-infective properties [18]. For instance, the flavonoids quercetin and kaempferol, as well as the flavonoid glycosides rutin and isoquercitrin, were reported to have antibacterial and antifungal activities [19]. Quercetin and kaempferol are known to be the most common flavonols present in many plants, and occur in different glycosidic forms. In many studies, they or their various glycosides have been proved to possess antimicrobial activity or, in other words, the antimicrobial activity of plant extracts (e.g., Rubus ulmifolius, Combretum erythrophyllum, Morus alba, Trollius chinensis, and propolis) has been attributed to quercetin and kaempferol [20-25]. 


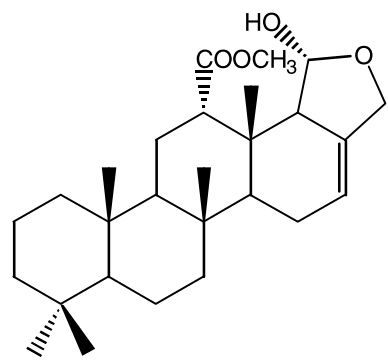

(1)

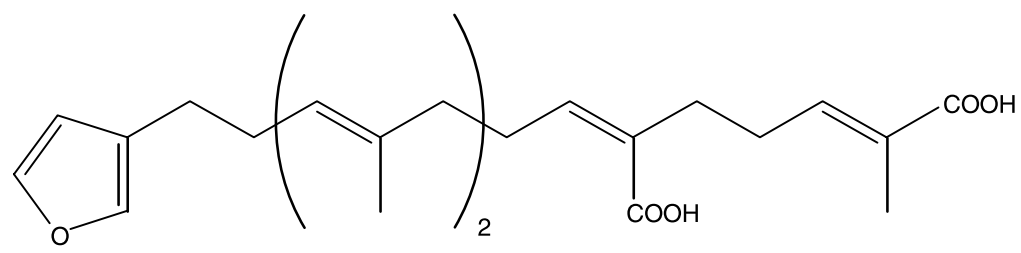

(2)

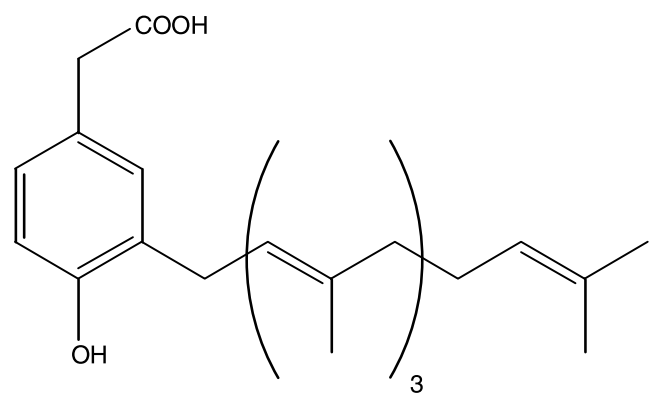

(3)

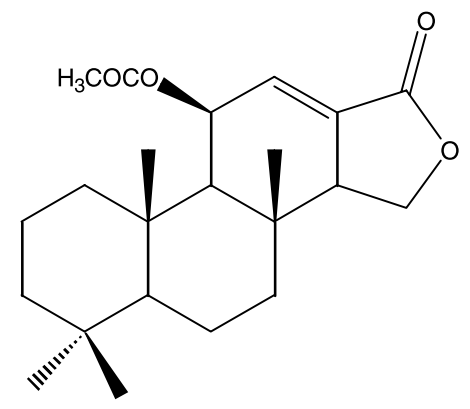

(4)

Fig. 1 Chemical structures of the antibacterial terpenes of marine origin 
In one of our recent studies, we examined antimicrobial and antiviral activities of four flavonoid derivatives, namely, scandenone (5), tiliroside (6), quercetin-3,7-O- $\alpha$-L-dirhamnoside (7), and kaempferol 3,7-O- $\alpha$-Ldirhamnoside (8) as shown in Fig. 2. These were tested against E. coli, P. aeruginosa, Proteus mirabilis, Klebsiella pneumoniae, Acinetobacter baumannii, S. aureus, B. subtilis, and Enterococcus faecalis, as well as the fungus Candida albicans by the microdilution method [26]. In addition, both DNA virus Herpes simplex (HSV) and RNA virus Parainfluenza (PI-3) were employed for antiviral assessment of the compounds using Madin-Darby bovine kidney (MDBK) and Vero cell lines.

All four compounds were found to be most active against $S$. aureus and E. faecalis, with a minimum inhibitory concentration (MIC) of $0.5 \mu \mathrm{g} / \mathrm{mL}$, followed by E. coli $(2 \mu \mathrm{g} / \mathrm{mL}), K$. pneumoniae $(4 \mu \mathrm{g} / \mathrm{mL})$, A. baumannii, and B. subtilis $(8 \mu \mathrm{g} / \mathrm{mL})$. $P$. mirabilis and $P$. aeruginosa were the most resistant bacteria against the compounds ( 16 and $32 \mu \mathrm{g} / \mathrm{mL}$, respectively). Notably, antibacterial activity of the compounds was as potent as ampicillin (AMP) and oflaxocin (OFX) towards S. aureus and E. faecalis. These compounds also possessed quite remarkable antifungal activity against $C$. albicans, as much as ketocanozole (KET) $(1 \mu \mathrm{g} / \mathrm{mL})$.

As shown in Table 1, none of the compounds had the ability to inhibit HSV, while only quercetin-3,7-O- $\alpha$-L-dirhamnoside had inhibitory activity against $\mathrm{PI}-3$ in the range $8-32 \mu \mathrm{g} / \mathrm{mL}$ of maximum and minimum cytopathogenic effect (CPE) inhibitory concentrations, respectively. The inhibitory concentration range of this compound is on a vast scale, which resembles that of oseltamivir (32 to $<0.25 \mu \mathrm{g} / \mathrm{mL}$ ). Besides, its maximum non-toxic concentration (MNTC) $(64 \mu \mathrm{g} / \mathrm{mL})$ was observed to be better than oseltamivir $(32 \mu \mathrm{g} / \mathrm{mL})$.

One of the undisputed functions of flavonoids and related polyphenols is their role in protecting plants against microbial invasion, which accumulate phytoalexins in response to microbial attack plants. Moreover, it is evident that a structure-activity relationship exists between the various flavonoids and their antimicrobial activity in most cases. A large number of antimicrobial flavonoids have been reviewed brilliantly and their SARs discussed [2732]. The majority of antifungal flavonoids have been observed to have either isoflavonoid, flavan, or flavanone structures such as maackiain, mucronulatol, luteolin 7-(2" -sulfatoglucoside), etc., which is consistent with our data on flavonoids. Accordingly, the presence of a phenolic group in the flavonoid structure suggests that it is necessary for antimicrobial activity. Interestingly, increasing the number of hydroxyl, methoxyl, or glycosyl substituents resulted in the steady loss of antifungal effect of the flavonoids [33]. In the review of Bylka et al. [34], it was suggested that the antibacterial effect towards Gram-negative bacteria is higher with flavones, while flavonoids containing two or three hydroxy groups in rings A and B are more active in inhibition of Gram-positive bacteria. However, in our study, all four flavonoid derivatives, 


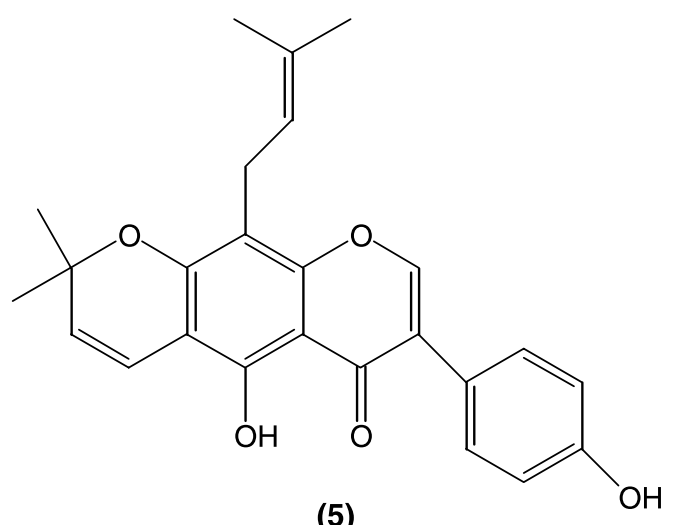

(5)

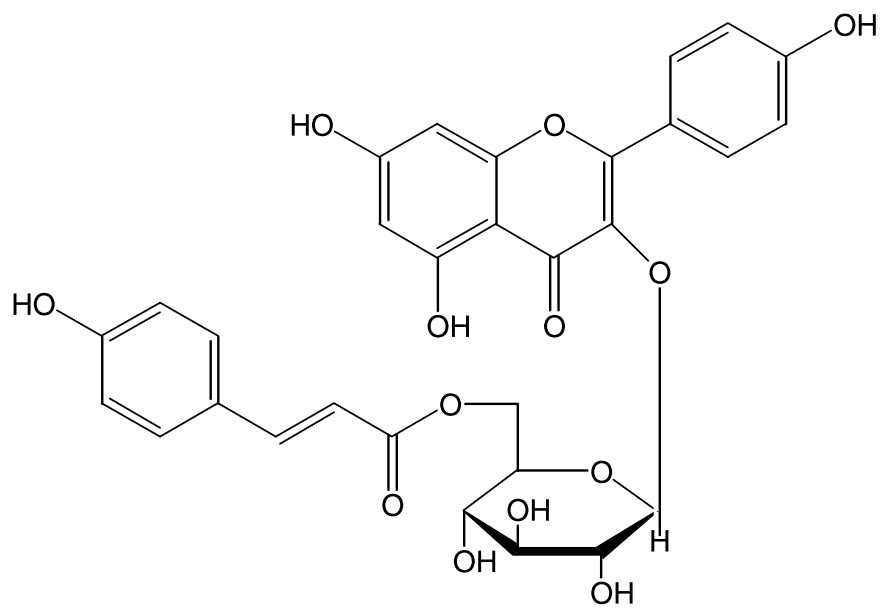

(6)<smiles>[R]c1cc(-c2oc3cc(O[14CH2][R6]([H])([H])[H])cc(O)c3c(=O)c2O[R6]c2ccccc2)ccc1O</smiles>

(7) $\mathrm{R}=\mathrm{OH}$

(8) $\mathrm{R}=\mathrm{H}$

Fig. 2 Chemical structures of the flavonoid derivatives with antimicrobial activity 
Table 1 Antiviral activity and cytotoxicity of the flavonoid derivatives screened

\begin{tabular}{|c|c|c|c|c|c|c|}
\hline \multirow{3}{*}{ Compounds } & \multicolumn{3}{|c|}{ MDBK cells } & \multicolumn{3}{|c|}{ Vero cells } \\
\hline & \multirow[t]{2}{*}{ MNTC } & \multicolumn{2}{|c|}{$\begin{array}{l}\text { CPE inhibitory } \\
\text { conc. vs HSV }\end{array}$} & \multicolumn{2}{|c|}{ MNTC } & $\begin{array}{l}\text { PE inhibitory } \\
\text { conc. vs PI-3 }\end{array}$ \\
\hline & & $\begin{array}{l}\text { Max. } \\
(\mu \mathrm{g} / \mathrm{mL})\end{array}$ & $\begin{array}{l}\text { Min. } \\
(\mu \mathrm{g} / \mathrm{mL})\end{array}$ & & $\begin{array}{l}\text { Max. } \\
L(\mu g / m L)\end{array}$ & $\begin{array}{l}\text { Min. } \\
(\mu \mathrm{g} / \mathrm{mL})\end{array}$ \\
\hline Scandenone & 64 & - & - & 64 & - & - \\
\hline Tiliroside & 64 & - & - & 64 & - & - \\
\hline $\begin{array}{l}\text { Quercetin-3,7-O- } \alpha- \\
\text { L-dirhamnoside }\end{array}$ & 64 & - & - & 64 & 32 & 8 \\
\hline $\begin{array}{l}\text { Kaempferol-3,7- } O-\alpha-6 \\
\text { L-dirhamnoside }\end{array}$ & & - & - & 64 & - & - \\
\hline Acyclovir & 16 & 16 & $<0.25$ & - & - & - \\
\hline Oseltamivir & - & - & - & 32 & 32 & $<0.25$ \\
\hline
\end{tabular}

consisting of one prenylated isoflavone and three flavonol glycosides, exhibited an equal strength of antibacterial and antifungal activities, independent of their structural substitutions.

Recently, flavonoids have been investigated from the viewpoint of their antiviral effect, particularly against the human immunodeficiency virus (HIV), the causative agent of acquired immonodeficiency syndrome (AIDS). Among them, quercetin has been shown to be effective against divergent virus types by many researchers, which supports our data on quercetin-3,7-O$\alpha$-L-dirhamnoside [26]. In one of the earliest studies, oral application of quercetin in mice was found to display a protective effect towards intraperitoneal encephalomyocarditis, Mengo $o_{\mathrm{M}, \mathrm{L}}$ and Mengo $_{\mathrm{M}}$ virus infections, but not against intracerebral challenge with $\mathrm{Mengo}_{\mathrm{M}}$ virus. It was not virucidal and did not interfere with Mengo virus replication in L cells [35]. The potentiative interaction of quercetin with murine $\alpha / \beta$ interferon in mice against Mengo virus infection [36] was also proved. Moreover, quercetin was reported to greatly enhance the antiviral effect of tumor necrosis factor (TNF) that produces a dose-dependent inhibition of vesicular stomatitis virus, Encephalomyocarditis virus, and HSV type-1 replication in WISH cells [37]. In another study, the effect of different substituents of quercetin and luteolin on the ability to inhibit the HSV type- 1 replication in RK-13 cells was studied [38].

In conclusion, our results demonstrated that scandenone, tiliroside, quercetin-3,7-O- $\alpha$-L-dirhamnoside, and kaempferol-3,7-O- $\alpha$-L-dirhamnoside possessed severe antibacterial and antifungal activities, whereas only quercetin-3,7-O- $\alpha$-L-dirhamnoside exerted noticeable anti-PI-3 activity. 


\section{2}

\section{Alkaloids}

\subsection{1}

\section{Diterpene Alkaloids}

The genus Consolida, Aconitum, and Delphinium (Ranunculaceae) are wellknown to be rich in diterpene alkaloids, which possess a diverse range of biological activities. These plants have also been the cause of poisonings, which primarily occur in cattle as well as human beings, due to toxicity of their alkaloids. In one of our recent studies, five diterpenoid-derivative alkaloids, lycoctonine (9), 18-O-methyllycoctonine (10), delcosine (11), 14acetyldelcosine (12), and 14-acetylbrowniine (13) (as shown in Fig. 3) were screened for their antibacterial, antifungal, and antiviral activities [39].

Once more, HSV and PI-3 were employed for antiviral assessment of the compounds using MDBK and Vero cell lines. Their MNTC and CPE values were determined using acyclovir and oseltamivir as the references. Besides antibacterial and antifungal activities, the alkaloids were tested against E. coli, $P$. aeruginosa, $P$. mirabilis, K. pneumoniae, A. baumannii, S. aureus, and $B$. subtilis, as well as the fungus $C$. albicans by the microdilution method as compared to the references AMP, OFX, and KET.

The results pointed out that these alkaloids possessed the highest antibacterial activity against $K$. pneumoniae and A. baumannii at $8 \mu \mathrm{g} / \mathrm{mL}$ concentration (Table 2), whereas they were moderately active to the rest of the bacteria. However, all the alkaloids tested were highly effective against $C$. albicans in a comparable manner to KET in the antifungal screening. Conversely, a selective inhibition was observed towards PI-3 virus by these alkaloids, while they were entirely unsuccessful on inhibition of HSV (Table 3).

PI-3 inhibitory activity of the alkaloids was fairly analogous to that of oseltamivir, ranging between $8-32 \mu \mathrm{g} / \mathrm{mL}$ as minimum and maximum inhibitory concentrations for the CPE. Our results showed that the alkaloids possessed rather high antifungal activity against $C$. albicans and a compelling antibacterial effect only against $K$. pneumoniae and A. baumannii, while they exerted a strong inhibition against PI-3.

Even though much is already known about the toxicity of diterpene alkaloids that contribute to the toxicity of Consolida, Delphinium, and Aconitium species, no antiviral study has been so far reported on this type of alkaloids. Therefore, no SAR studies have been encountered by us on the antiviral or antimicrobial activities of these alkaloids. However, a quantitative SAR analysis performed on a number of diterpene alkaloids isolated from an Aconitum sp. indicated that biological activity of these alkaloids may be related to their toxicity rather than to a specific pharmacological action [40]. In a current study on 43 norditerpenoid alkaloids from Consolida, Delphinium, and Aconitum species against several tumor cell lines, lycoctonine and browniine were 


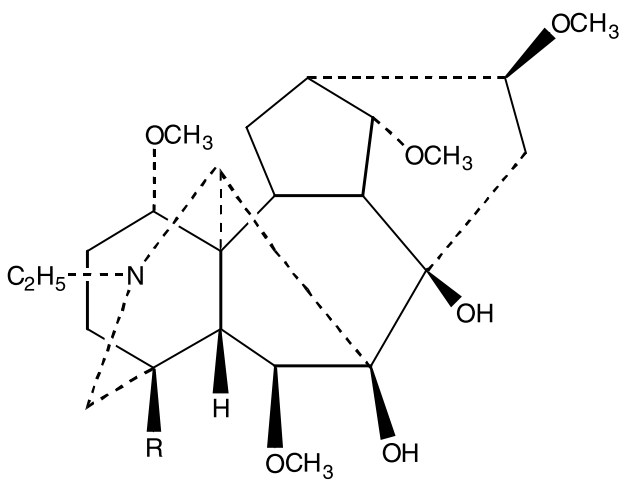

(9) $\mathrm{R}=\mathrm{CH}_{2} \mathrm{OH}$

(10) $\mathrm{R}=\mathrm{CH}_{2} \mathrm{OCH}_{3}$

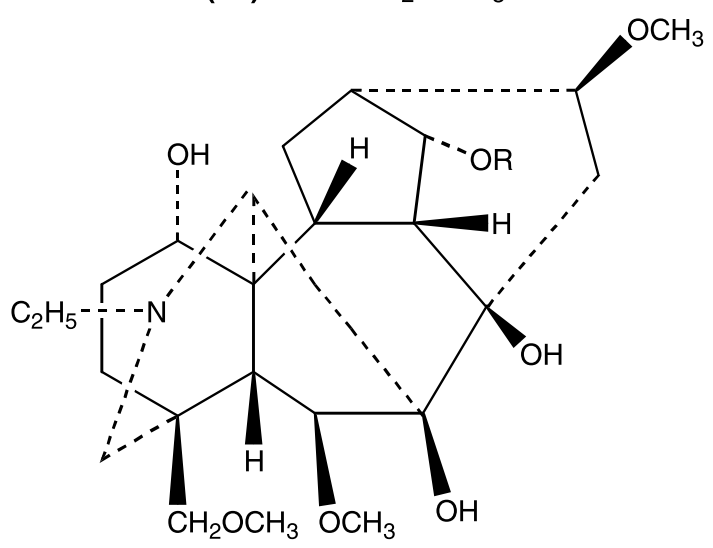

(11) $\mathrm{R}=\mathrm{H}$

(12) $\mathrm{R}=\mathrm{COCH}_{3}$

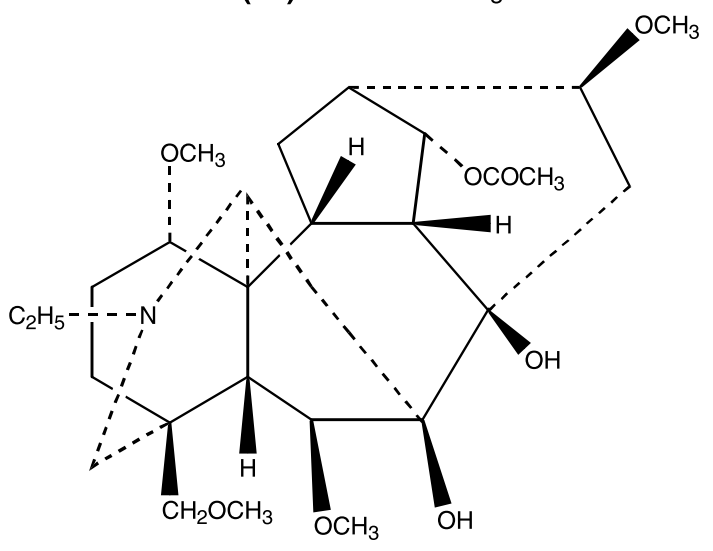

(13)

Fig. 3 Chemical structures of the diterpene alkaloids with antimicrobial activity 


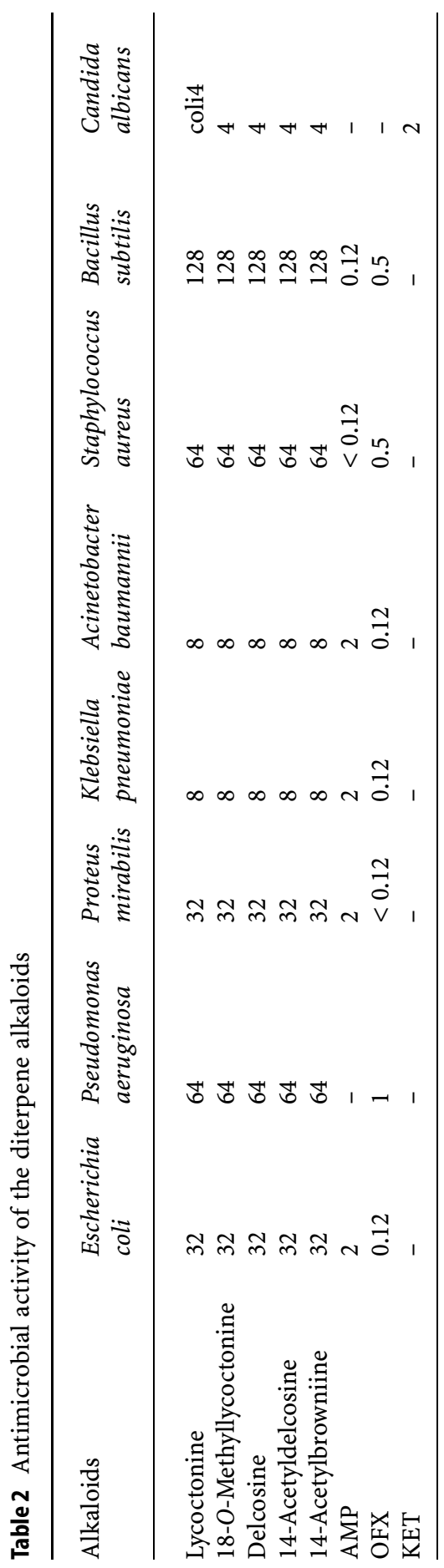


Table 3 Antiviral activity and cytotoxicity of the diterpene alkaloids

\begin{tabular}{|c|c|c|c|c|c|c|}
\hline \multirow{3}{*}{ Alkaloids } & \multicolumn{3}{|c|}{ MDBK cells } & \multicolumn{3}{|c|}{ Vero cells } \\
\hline & \multirow[t]{2}{*}{ MNTC } & \multicolumn{2}{|c|}{$\begin{array}{l}\text { CPE inhibitory } \\
\text { conc. vs HSV }\end{array}$} & MNTC & \multicolumn{2}{|c|}{$\begin{array}{l}\text { CPE inhibitory } \\
\text { conc. vs PI-3 }\end{array}$} \\
\hline & & $\begin{array}{l}\text { Max. } \\
(\mu \mathrm{g} / \mathrm{mL})\end{array}$ & $\begin{array}{l}\text { Min. } \\
(\mu \mathrm{g} / \mathrm{mL})\end{array}$ & $(\mu \mathrm{g} / \mathrm{mL})$ & $\begin{array}{l}\text { Max. } \\
(\mu \mathrm{g} / \mathrm{mL})\end{array}$ & $\begin{array}{l}\text { Min. } \\
(\mu \mathrm{g} / \mathrm{mL})\end{array}$ \\
\hline Lycoctonine & 64 & - & - & 32 & 32 & 8 \\
\hline 18-O-methyllycoctonine & 64 & - & - & 64 & 32 & 1 \\
\hline Delcosine & 64 & - & - & 64 & 32 & 1 \\
\hline 14-Acetyldelcosine & 64 & - & - & 64 & 32 & 1 \\
\hline 14-Acetylbrowniine & 64 & - & - & 64 & 32 & 1 \\
\hline Acyclovir & 16 & 16 & $<0.25$ & - & - & - \\
\hline Oseltamivir & - & - & - & 32 & 32 & $<0.25$ \\
\hline
\end{tabular}

found to be active among those screened [41]. In contrast to this data, lycoctonine and 14-acetyl derivative of browniine in our study showed a lesser amount of cytotoxicity on MDBK and Vero cell lines at $64 \mu \mathrm{g} / \mathrm{mL}$. GonzalesColoma et al. studied antifeedant activity and toxicity of some diterpene alkaloids (15-acetylcardiopetamine, cardiopetamine along with its amino alcohol, the $\beta, \gamma$ unsaturated ketone, and the acetylated ketone derivatives) from Delphinium sp. on the insects Spodoptera littoralis and Leptinotarsa decemlineata [42]. Results of the study showed that the C13 and C15 hydroxy substituents are essential features of the active molecule, while the C11 benzoate group enhanced the biological effect on both insect species, where all of our alkaloids lacked those two substituents.

In a taxonomic study done in 2002, lycoctonine-type alkaloids isolated from three Delphinium species were classified into three groups according to the degree of their toxicity: $N$-(methylsuccinyl)-anthranoyllycoctonine (MAL)-type with high toxicity, lycoctonine-type with moderate toxicity, and 7,8-methylene-dioxylycoctonine (MDL)-type with low toxicity [43]. In that paper, it was reported that the moiety attached to C14 is quite important for the toxicity of these alkaloids, which is also in accordance with our present data. Furthermore, other functionalities on these molecules are also notable in terms of toxicity. It was noticed that the tertiary nitrogen, anthranilic acid substitution, and $\mathrm{C} 1$ moiety affect the toxicity degree within those alkaloids. For instance, when the methylsuccinyl group is removed from MAL (which then converts to lycoctonine), lycoctonine becomes 93 times less toxic.

Briefly, our report was the first on antiviral, antibacterial, and antifungal activities of lycoctonine, 18-O-methyllycoctonine, delcosine, 14-acetyldelcosine, and 14-acetylbrowniine. Furthermore, our data also suggest that all of the diterpene alkaloids are worthy of being evaluated for their antimicrobial and antiviral activities for future-promising results. 


\subsection{2}

\section{Isoquinoline Alkaloids}

In our recent work, we focused on investigation of antiviral activity of 33 isoquinoline alkaloids and seven derivatives of them, which are classified as protopine-type [protopine (14) and $\beta$-allocryptopine (15)], benzylisoquinoline-type $[(+)$-reticuline $(16)$ and (+)-norjuziphine], benzophenantridine-type [sanguinarine (17), norsanguinarine, and chelidimerine (18)], spirobenzylisoquinoline-type [fumarophycine (19), fumarophycine acetate, $(-)$-corpaine, $( \pm)$-sibiricine (20), sibiricine acetate, $( \pm)$-dihydrosibiricine, (+)-fumariline, (-)-dihydrofumariline, $(+)$-parfumine, parfumine acetate, dihydroparfumine acetate], phtalideisoquinoline-type [ $\alpha$-hydrastine (21), (+)-bicuculline, (-)-bicuculline, and (-)-adlumidine], aporphine-type $[(+)$-bulbocapnine (22) and (+)-isoboldine], protoberberine-type [berberine (23), (-)-stylopine, (-)-canadine, (-)-sinactine, (-)-ophiocarpine (24), ophiocarpine- $N$-oxide, corydalmine, palmatine, $( \pm)$-corydalidzine, dehydrocorydaline, and dehydrocavidine], cularine-type [(+)-cularicine (25), oxocularine, oxosarcocapnine, and oxosarcocapnidine], and an isoquinolone [corydaldine (26)], against HSV and PI-3 using MDBK and Vero cell lines [44], whose isolation procedures were described elsewhere [45-50] (Figs. 4 and 5). Moreover, the alkaloids were also tested against E. coli, P. aeruginosa, $P$. mirabilis, $K$. pneumoniae, A. baumannii, S. aureus, and B. subtilis, as well as the fungus C. albicans by the microdilution method, for their antibacterial and antifungal activities.

According to our findings, all types of the alkaloids appeared to be more active to Gram-negative bacteria than to Gram-positive ones. Most of the alkaloids, including protopine, $\beta$-allocryptopine, chelidimerine, fumarophycine, $( \pm)$-sibiricine, sibiricine acetate, $( \pm)$-dihydrosibiricine, parfumine acetate, $\alpha$-hydrastine, (+)-bulbocapnine, berberine, (-)-canadine, (-)-ophiocarpine, ophiocarpine- $N$-oxide, corydalmine, oxosarcocapnidine, and corydaldine, showed significant inhibition on K. pneumoniae and A. baumannii, in particular, better than the rest of the Gram-negatives, at $8 \mu \mathrm{g} / \mathrm{mL}$ concentration as compared to AMP $(2 \mu \mathrm{g} / \mathrm{mL})$. All of the alkaloids, regardless of their structural differences, inhibited E. coli and P. mirabilis with MIC of $32 \mu \mathrm{g} / \mathrm{mL}$, while they inhibited S. aureus at $64 \mu \mathrm{g} / \mathrm{mL}$. Interestingly, the alkaloids that were found to inhibit K. pneumoniae and A. baumannii at $8 \mu \mathrm{g} / \mathrm{mL}$ also had remarkable inhibition on C. albicans $(4 \mu \mathrm{g} / \mathrm{mL})$, while a notable occurrence of antifungal activity was observed with the rest at $8 \mu \mathrm{g} / \mathrm{mL}$ concentration.

The tested isoquinolines were observed to display a selective inhibition against PI-3 as seen in Table 4, except for (+)-isoboldine, (-)-stylopine, and $( \pm)$-corydalidzine, that were totally ineffective against both viruses. Protopine, $\beta$-allocryptopine, chelidimerine, fumarophycine, $\alpha$-hydrastine, (+)-bulbocapnine, $(+)$-isoboldine, $(-)$-sinactine, palmatine, dehydrocoryda- 
<smiles>CN1CCc2cc3c(cc2C(=O)Cc2ccc4c(c2C1)OCO4)OCO3</smiles>

(14)<smiles>COc1ccc(CC2c3cc(O)c(OC)cc3CCN2C)cc1O</smiles>

(16)<smiles>COc1ccc(CC(=O)c2cc3c(cc2CCN(C)Cc2c(OC)ccc(OC)c2C)OCO3)cc1</smiles>

(15)<smiles>C[n+]1cc2c3c(ccc2c2ccc4cc5c(cc4c21)OCO5)OCO3</smiles>

(17)

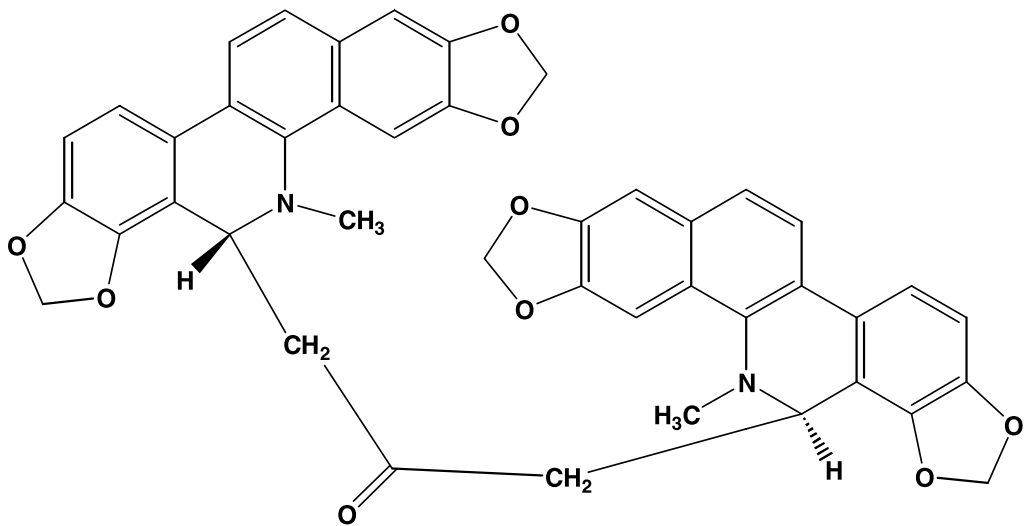

(18)

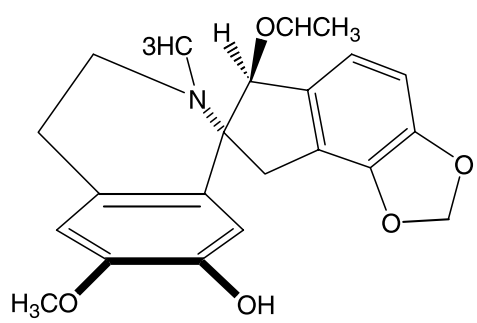

(19)

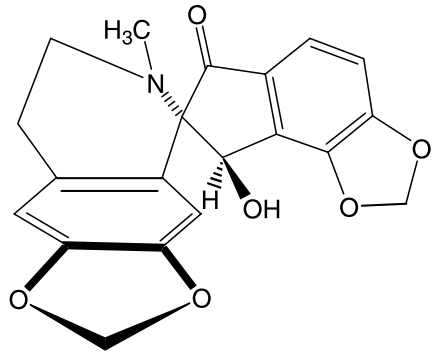

(20)

Fig. 4 Chemical structures of the isoquinoline alkaloids with antimicrobial activity 
<smiles>COc1ccc2c(c1OC)C(=O)O[C@H]2C1c2cc3c(cc2CCN1C)OCO3</smiles>

(21)<smiles></smiles>

(23)<smiles>COc1cc2c(cc1OC)Oc1c(OC)ccc3c1C(C2)N(C)CC3</smiles>

(25)<smiles>COc1ccc2c(c1O)-c1c3c(cc4c1[C@@H](C2)N(C)CC4)OCO3</smiles>

(22)<smiles>COc1ccc2c(c1OC)CN1CCc3cc4c(cc3C1C2O)OCO4</smiles>

(24)<smiles>COc1cc2c(cc1OC)C(=O)NCC2</smiles>

(26)

Fig. 5 continues from Fig. 4

line, dehydrocavidine, (+)-cularicine, oxocularine, and oxosarcocapnine were completely inactive against HSV, whereas maximum CPE concentrations of the rest were the same as acyclovir $(16 \mu \mathrm{g} / \mathrm{mL})$. However, the alkaloids were revealed to be less cytotoxic than acyclovir on MDBK cells, (-)-canadine being the least cytotoxic alkaloid $(128 \mu \mathrm{g} / \mathrm{mL})$. The most active alkaloid with anti-PI-3 effect was shown to be protopine $(1-32 \mu \mathrm{g} / \mathrm{mL})$, followed by fumarophycine $(2-32 \mu \mathrm{g} / \mathrm{mL})$, chelidimerine, (+)-bulbocapnine, and (-)ophiocarpine $(4-32 \mu \mathrm{g} / \mathrm{mL})$, as well as $\beta$-allocriptopine and oxosarcocapni- 
Table 4 activity and cytotoxicity of the isoquinoline alkaloids studied

\begin{tabular}{|c|c|c|c|c|c|c|}
\hline \multirow{3}{*}{ Alkaloids } & \multicolumn{3}{|c|}{ MDBK cells } & \multicolumn{3}{|c|}{ Vero cells } \\
\hline & \multirow[t]{2}{*}{ MNTC } & \multicolumn{2}{|c|}{$\begin{array}{l}\text { CPE inhibitory } \\
\text { conc. vs HSV }\end{array}$} & MNTC & \multicolumn{2}{|c|}{$\begin{array}{l}\text { CPE inhibitory } \\
\text { conc. vs PI-3 }\end{array}$} \\
\hline & & $\begin{array}{l}\text { Max. } \\
(\mu \mathrm{g} / \mathrm{mL})\end{array}$ & $\begin{array}{l}\text { Min. } \\
(\mu \mathrm{g} / \mathrm{mL})\end{array}$ & $(\mu \mathrm{g} / \mathrm{n}$ & $\begin{array}{l}\text { Max. } \\
\mathrm{hL})(\mu \mathrm{g} / \mathrm{mL})\end{array}$ & $\begin{array}{l}\text { Min. } \\
(\mu \mathrm{g} / \mathrm{mL})\end{array}$ \\
\hline Protopine & 64 & - & - & 32 & 32 & 1 \\
\hline$\beta$-Allocryptopine & 64 & - & - & 32 & 32 & 8 \\
\hline (+)-Reticuline & 32 & 16 & - & 64 & 32 & 16 \\
\hline (+)-Norjuziphine & 32 & 16 & - & 64 & 32 & 16 \\
\hline Sanguinarine & 32 & 16 & - & 32 & 32 & 16 \\
\hline Norsanguinarine & 32 & 16 & - & 32 & 32 & 16 \\
\hline Chelidimerine & 64 & - & - & 32 & 32 & 4 \\
\hline Fumarophycine & 64 & - & - & 32 & 32 & 2 \\
\hline $\begin{array}{l}\text { (-)-Fumarophycine } \\
\text { acetate }\end{array}$ & 32 & 16 & - & 64 & 32 & 16 \\
\hline (-)-Corpaine & 32 & 16 & - & 64 & 32 & 16 \\
\hline$( \pm)$-Sibiricine & 32 & 16 & - & 64 & 32 & 16 \\
\hline Sibiricine acetate & 32 & 16 & - & 32 & 32 & 16 \\
\hline$( \pm)$-Dihydrosibiricine & 32 & 16 & - & 64 & 32 & 16 \\
\hline (+)-Fumariline & 32 & 16 & - & 64 & 32 & 16 \\
\hline (-)-Dihydrofumariline & 32 & 16 & - & 64 & 32 & 16 \\
\hline (+)-Parfumine & 32 & 16 & - & 64 & 32 & 16 \\
\hline Parfumine acetate & 32 & 16 & - & 64 & 32 & 16 \\
\hline $\begin{array}{l}\text { (-)-Dihydroparfumine } \\
\text { diacetate }\end{array}$ & 32 & 16 & - & 64 & 32 & 16 \\
\hline$\alpha$-Hydrastine & 64 & - & - & 64 & 32 & 16 \\
\hline (+)-Bicuculline & 32 & 16 & - & 64 & 32 & 16 \\
\hline (-)-Bicuculline & 32 & 16 & - & 64 & 32 & 16 \\
\hline (-)-Adlumidine & 32 & 16 & - & 64 & 32 & 16 \\
\hline (+)-Bulbocapnine & 64 & - & - & 32 & 32 & 4 \\
\hline$(+)$-Isoboldine & - & - & - & - & - & - \\
\hline Acyclovir & 16 & 16 & $<0.25$ & - & - & - \\
\hline Oseltamivir & - & - & - & 32 & 32 & $<0.25$ \\
\hline Berberine & 64 & - & - & 32 & - & - \\
\hline (-)-Stylopine & - & - & - & - & - & 16 \\
\hline (-)-Canadine & 128 & - & - & 64 & 32 & 16 \\
\hline$(-)$-Sinactine & 32 & 16 & - & 64 & 32 & 16 \\
\hline (-)-Ophiocarpine & 64 & - & - & 32 & 32 & 4 \\
\hline Ophiocarpine- $N$-oxide & 64 & - & - & 32 & 32 & 16 \\
\hline Corydalmine & 64 & - & - & 64 & 64 & 32 \\
\hline Palmatine & 32 & 16 & - & 32 & 32 & 16 \\
\hline$( \pm)$-Corydalidzine & - & - & - & - & - & - \\
\hline Dehydrocorydaline & 32 & 16 & - & 64 & - & 16 \\
\hline Dehydrocavidine & 32 & 16 & - & 64 & 32 & 16 \\
\hline (+)-Cularicine & 32 & 16 & - & 32 & 32 & 16 \\
\hline
\end{tabular}


Table 4 (continued)

\begin{tabular}{|c|c|c|c|c|c|c|}
\hline \multirow{3}{*}{ Alkaloids } & \multicolumn{3}{|c|}{ MDBK cells } & \multicolumn{3}{|c|}{ Vero cells } \\
\hline & \multirow[t]{2}{*}{ MNTC } & \multicolumn{2}{|c|}{$\begin{array}{l}\text { CPE inhibitory } \\
\text { conc. vs HSV }\end{array}$} & \multicolumn{2}{|c|}{ MNTC } & $\begin{array}{l}\text { nibitory } \\
\text { is PI-3 }\end{array}$ \\
\hline & & $\begin{array}{l}\text { Max. } \\
(\mu \mathrm{g} / \mathrm{mL})\end{array}$ & $\begin{array}{l}\text { Min. } \\
(\mu \mathrm{g} / \mathrm{mL})\end{array}$ & $(\mu \mathrm{g})$ & $\begin{array}{c}\text { Max. } \\
L)(\mu \mathrm{g} / \mathrm{mL})\end{array}$ & $\begin{array}{l}\text { Min. } \\
(\mu \mathrm{g} / \mathrm{mL})\end{array}$ \\
\hline Oxocularine & 32 & 16 & - & 64 & 32 & 16 \\
\hline Oxosarcocapnine & 32 & 16 & - & 64 & 32 & 16 \\
\hline Oxosarcocapnidine & 64 & - & - & 32 & 32 & 8 \\
\hline Corydaldine & 64 & - & - & 32 & 32 & 16 \\
\hline Acyclovir & 16 & 16 & $<0.25$ & - & - & - \\
\hline Oseltamivir & - & - & - & 32 & 32 & $<0.25$ \\
\hline
\end{tabular}

dine $(8-32 \mu \mathrm{g} / \mathrm{mL})$. The alkaloids tested exhibited lower or the same degree of cytotoxicity as oseltamivir $(32 \mu \mathrm{g} / \mathrm{mL})$ against Vero cells.

A number of antimicrobial, antiviral, antitumoral, antimalarial, and cytotoxicity studies have been so far reported on various derivatives of natural or synthetic isoquinoline alkaloids [51-57]. In one study, antimicrobial, cytotoxic, and anti-HIV activities of 26 simple isoquinolines and 21 benzylisoquinolines were investigated. The results showed that a quaternary nitrogen atom of isoquinoline or dyhydroisoquinoline type may enhance the potency of antimicrobial activity and cytotoxicity, whereas anti-HIV activity was higher with tetrahydroisoquinolines [58]. In the study of Cui et al., simple isoquinolines, 15 of which were of 1-benzylisoquinoline-type and 19 of which were of protoberberine-derivatives, were screened against Epstein-Barr virus early antigen (EBV-EA) activation induced by 12-O-tetradecanoylphorbol13-acetate (TPA), which is considered to be an indicator of antitumorpromoting activity. The study was carried out using Raji cells and all 1benzylisoquinolines and 11 of the protoberberines exerted higher inhibitory activity than $\beta$-carotene [59]. Regarding the structure-activity relationship, it was concluded that the inhibitory activity of 1-benzylisoquinolines increased as the number of hydroxyl groups on the aromatic ring increased and, additionally, the size of substituents at the $\mathrm{C} 8$ and $\mathrm{C} 13$, as well as type and position of the oxygenated substituents on $\mathrm{A}$ and $\mathrm{D}$ rings, influenced the virus inhibition. Moreover, derivatives of the isoquinoline skeleton attached with carboxamide moiety were declared to be the potent and selective inhibitors of human cytolamegavirus [60].

In another study, the structure-activity relationships of berberine and its derivatives were examined for their antibacterial activity. Among the 13-alkyl-substituted and the 13-unsubstituted protoberberinium salts, an increase in antibacterial activity was observed with the 13-ethyl-9-ethoxyl, the 13-ethyl, and the 13-methyl derivatives against $S$. aureus by eight-, four-, 
and twofold, respectively, over berberine, which suggested that steric effects played an noteworthy role in the antibacterial activity [61]. Additionally, replacement of methoxyl groups at the $\mathrm{C} 2$ and the $\mathrm{C} 3$ of ring A by a methylenedioxy group caused a boost in activity. In this report, it was stated that the quaternary nitrogen atom (such as in protoberberinium salts) an alkylsubstituent at $\mathrm{C} 13$, and a methylenedioxy function at $\mathrm{C} 2$ and $\mathrm{C} 3$ are required for enhanced antibacterial activity. In a study by Nakamoto et al., berberine was revealed to have a strong antifungal effect against $C$. albicans, $C$. tropicalis, and C. glabrata, respectively, which is in accordance with our data on berberine [62]. In a recent publication, a high occurrence of antibacterial activity in berberine was shown towards E. coli, K. pneumoniae, P. aeruginosa, P. fluorescens, S. aureus, Salmonella typhi, Enterococcus sp., and Serratia marcescens, showing a better activity than streptomycin at $50 \mu \mathrm{g} / \mathrm{mL}$ by paper disc diffusion method. Consequently, berberine was concluded to be responsible for the high antibacterial activity of Coscinium fenestratum [63]. However, we found that berberine was only active against $K$. pneumoniae and $A$. baumannii by microdilution method, which might result from the application of two different methods. In another former study, berberine obtained from Berberis heterophylla was tested against the ATCC strains of S. aureus, Enterecoccus faecalis, P. aeruginosa, E. coli, and C. albicans by agar diffusion method at 50,100, and $200 \mu \mathrm{g} / \mathrm{mL}$ concentrations. The alkaloid was highly active against $S$. aureus at 100 and $200 \mu \mathrm{g} / \mathrm{mL}$, whereas it did not possess any inhibitory effect against E. faecalis, P. aeruginosa, and E. coli [64]. This data was consistent with ours for berberine in the case of $E$. coli and $P$. aeruginosa. It was not active to $S$. aureus, which might again be the result of the use of two dissimilar methods. In the same work, antifungal activity screening was performed with berberine using the clinical strains of several Candida sp. such as C. albicans, C. glabrata, C. haemulonii, C. lusitaniae, C. krusei, and C. parapsilosis. Being the most active to C. krusei, followed by the rest in decreasing degrees of effectiveness, berberine was expressed as a novel antifungal agent.

In one report, protopine and $\alpha$-allocryptopine isolated from Glaucium oxylobum were tested for their antifungal activity against Microsporium canis, M. gypseum, Tricophyton mentagrophytes, Epidermophyton floccosum, C. albicans, Aspergillus niger, and Penicillium sp. [65]. Among these fungi, protopine exerted low activity against $M$. canis and T. mentagrophytes, while $\alpha$-allocryptopine had low activity towards M. gypseum and good inhibition of E. floccosum. In contrast, protopine was found to be inactive against $C$. albicans, whereas this alkaloid had a high inhibition against the same fungus in our study $(4 \mu \mathrm{g} / \mathrm{mL})$. $\alpha$-Allocryptopine was also inactive against $C$. albicans, whose $\beta$-counterpart exhibited a very good antifungal effect against $C$. albicans. This may reasonably be due to the $\alpha$ - and $\beta$-conformation of the compound. In a previous study, the molluscicidal activity of Argemone mexicana seeds were tested against the snail Lymnaea acumi- 
nata, which led to isolation of protopine and sanguinarine as the active components [66].

From the structure-activity point of view, a few features about the isoquinoline alkaloids investigated herein can be pointed out. The quaternary nitrogen atom found on some of the isoquinolines such as dehydrocorydaline, dehydrocavidine, berberine, sanguinarine, and palmatine may have an effect on the decrease of antiviral activity. On the other hand, the synergistic interaction among the isoquinoline alkaloids isolated from $F$. vaillantii may be stated to contribute to the higher antiviral activity of this extract. Protopinetype alkaloids seem to display a higher antiviral effect than the rest.

\section{3}

\section{Conclusion}

From ancient to modern history, traditional plant-based medicines have played an important role in health care. Many countries in Africa, Asia, and Latin America still rely on traditionally used herbal medicines for primary health care needs. On the other hand, the complex nature of plant extracts and the high probability of competing or synergistic bioactivities within the same extract mean that these results represent the starting point for an activity-guided search for active plant metabolites. It is also evident that a structure-activity relationship exists between the various chemical structures and their antimicrobial activity in most cases. However, antiviral agents, unlike antibacterial drugs which may cover a wide range of pathogens, tend to be narrow in spectrum, and, unfortunately, have a limited efficacy. Historically, the discovery of antiviral drugs has been largely fortuitous. Spurred on by success with antibiotics, drug companies launched huge blind-screening programs with relatively little success. Besides, lead compounds were modified by scientists in an attempt to improve bioactivity. However, there is still a great need to develop more effective antiviral and antimicrobial drug molecules.

As a conclusion, these findings provide additional evidence for the supposition that the assays mentioned above play the part of useful primary screening in the survey of bioactive natural products. For the reasons outlined above, it is very important to focus on plants to discern novel antivi$\mathrm{ral} /$ antimicrobial compounds. Therefore, we truly hope that our studies, as well as similar reports by different researchers, may help find new antimicrobials/antivirals from herbal sources.

\section{References}

1. Alekshun MN, Levy SB (2007) Cell 128:1037

2. Pesavento G, Ducci B, Comodo N, Lo Nostro A (2007) Food Cont 18:196 
3. Courvalin P (2006) Digest Liver Dis 38(Suppl2):S261

4. Sabet NS, Subramaniam G, Navaratnam P, Sekaran SD (2007) J Microbiol Meth 68:157

5. Kardas P, Devine S, Golembesky A, Roberts C (2005) Int J Antimicr Agents 26:106

6. Knox K, Lawson W, Dean B, Holmes A (2003) J Hosp Infec 53:85

7. Singer RS, Henrik RF, Wegener C, Bywater R, Walters J, Lipsitch M (2003) Lancet Infect Dis 3:47

8. Sahm DF, Benninger MS, Evangelista AT, Yee YC, Thornsberry C, Brown NP (2007) Otolaryngol-Head and Neck Surg 136:385

9. Lee YL, Cesario T, Gupta G, Flionis L, Tran C, Decker M, Thrupp L (1997) Am J Infec Cont 25:312

10. Donia M, Hamann MT (2003) The Lancet (Inf. Diseases) 3:338

11. Mayer AM, Hamann MT (2004) Mar Biotechnol 6:37

12. Mayer AM, Hamann MT (2005) Comp. Biochem Physiol C Toxicol Pharmacol 140: 265

13. Erdogan I, Şener B (2000) GUEDE-J Gazi Univ Fac Pharm 17:1

14. De Rosa S, De Giulio A, Iodice A (1994) J Nat Prod 57:1711

15. Kubo I, Muroi H, Kubo A (1993) J Agric Food Chem 41:2447

16. Kubo I, Muroi H, Himejima M, Kubo A (1993) Bioorg Med Chem Lett 3:1305

17. Inoue Y, Shiraishi A, Hada T, Hirose K, Hamashima H, Shimada J (2004) FEMS Microbiol Lett 237:325

18. Cushni TPT, Lamb AJ (2005) Int J Antimic Agents 26:343

19. Beschia M, Leonte A, Oencea I (1984) Bull Univ Galati Faso 6:23

20. Panizzi L, Caponi C, Catalano S, Cioni PL, Morelli I (2002) J Ethnopharmacol 79:165

21. Gatto MT, Falcocchio S, Grippa E, Mazzanti G, Battinelli L, Nicolasi G, Lambusta D, Saso L (2002) Bioorg Med Chem 10:269

22. Li YL, Ma SC, Yang YT, Ye SM, But PPH (2002) J Ethnopharmacol 79:365

23. Du J, He ZD, Jiang RW, Ye WC, Xu HX, But PPH (2003) Phytochemistry 62:1235

24. Martini N, Katerere DRP, Eloff JN (2004) J Ethnopharmacol 93:207

25. Kosalec I, Pepeljnjak S, Bakmaz M, Vladimir-Knezevic S (2005) Acta Pharm 55:423

26. Özcelik B, Orhan I, Toker G (2006) Z Naturforsch C 61:632

27. Harborne JB, Williams CA (2000) Phytochemistry 55:481

28. Perez RM (2003) Pharm Biol 41:107

29. Erlund I (2004) Nutr Res 24:851

30. Cushni TPT, Lamb AJ (2005) Int J Antimic Agents 26:343

31. Rios JL, Recio MC (2005) J Ethnopharmacol 100:80

32. Khan MTH, Ather A, Thompson KD, Gambari R (2005) Antiviral Res 67:107

33. Picman AK, Schneider EF, Pieman J (1995) Biochem Syst Ecol 23:683

34. Bylka W, Matlawska I, Pilewski NA (2004) JANA 7:24

35. Veckenstedt A, Puszhai R (1981) Antiviral Res 1:249

36. Veckenstedt A, Güttner J, Beladi I (1987) Antiviral Res 7:169

37. Ohnishi E, Bannai H (1993) Antiviral Res 22:327

38. Wleklik M, Luczak M, Panasiak W, Kobus M, Lammer-Zarawska E (1998) Acta Virol 32:522

39. Şener B, Orhan I, Özcelik B (2007) ARKIVOC 7:265

40. Bello-Ramirez AM, Nava-Ocampo AA (2004) Fund Clin Pharmacol 18:699

41. De Ineìs C, Reina M, Gaviìn JA, González-Coloma A (2006) Z Naturforsch C 61:11

42. Gonzalez-Coloma A, Guadano A, Gutierrez C, Cabrera R, De La Pena E, De La Fuente G, Reina M (1998) J Agric Food Chem 46:286

43. Panter KE, Manners GD, Stegelmeier BL, Lee S, Gardner DR, Ralphs MH, Pfister JA, James LF (2002) Biochem Syst Ecol 30:113 
44. Orhan I, Özcelik B, Karaoğlu T, Şener B (2007) Z Naturforsch C 62:19

45. Şener B, Gözler B, Minard RD, Shamma M (1983) Phytochemistry 22:2073

46. Şener B (1983) Int J Crude Drug Res 21:135

47. Şener B (1984) GUEDE-J Fac Pharm Gazi Univ 1:15

48. Sener B (1985) J Nat Prod 48:670

49. Şener B (1986) Int J Crude Drug Res 24:105

50. Şener B (1988) Int J Crude Drug Res 26:61

51. Capilla AS, Romero M, Pujol MD, Caignard DH, Renard P (2001) Tetrahedron 57:8297

52. An TY, Huang RQ, Yang Z, Zhang DK, Li GR, Yao YC, Gao J (2001) Phytochemistry 58:1267

53. Satou T, Koga M, Matsuhashi R, Koike K, Tada I, Nikaido T (2002) Vet Parasitol 104:131

54. Zhang Q, Tu G, Zhao Y, Cheng T (2002) Tetrahedron 58:6795

55. Gomez-Monterrey I, Campiglia P, Grieo P, Diurno MV, Bolognese A, La Colla P, Novellino E (2003) Bioorg Med Chem 11:3769

56. Morrell A, Antony S, Kohlhagen G, Pommier Y, Cushman M (2004) Bioorg Med Chem Lett 14:3659

57. Fischer DCH, Gualdo NCA, Bachiega D, Carvalho CS, Lupo FN, Bonotto SV, Alves MO, Yogi A, Di Santi SM, Avila PE, Kirchgatter K, Moreno PRH (2004) Acta Trop 92:261

58. Iwasa K, Moriyasu M, Tachibana Y, Kim HS, Wataya Y, Wiegrebe W, Bastow KF, Cosentino LM, Kozuka M, Lee KH (2001) Bioorg Med Chem 9:2871

59. Cui W, Iwasa K, Tokuda H, Kashihara A, Mitani Y, Hasegawa T, Nishiyama Y, Moriyasu M, Nishino H, Hanaoka M, Mukai C, Takeda K (2006) Phytochemistry 67:70

60. Chan L, Jin H, Stefanac T, Wang W, Lavallee JF, Bedard J, May S (1999) Bioorg Med Chem Lett 9:2583

61. Iwasa K, Kamiguchi M, Ueki M, Taniguchi M (1996) Eur J Med Chem 31:469

62. Nakamoto K, Sadamori S, Hamada T (1990) J Prost Dent 64:691

63. Nair GM, Narasimhan S, Shiburaj S, Abraham TK (2005) Fitoterapia 76:585

64. Freile ML, Giannini F, Pucci G, Sturniolo A, Rodero L, Pucci O, Balzareti V, Enriz RD (2003) Fitoterapia 74:702

65. Morteza-Semnani K, Amin G, Shidfar MR, Hadizadeh H, Shafiee A (2003) Fitoterapia 74:493

66. Singh S, Singh DK (1999) Chemosphere 38:3319 